\title{
Trade and Income Convergence in Selected South Asian \\ Countries and Their Trading Partners
}

\author{
Ahmed Nawaz Hakro* and Bashir Ahmad Fida**
}

\begin{abstract}
This paper analyzes trade among and the convergence of per capita income for India, Pakistan, Bangladesh, and Sri Lanka. The extent of trade and its relationship with the magnitude of income convergence is studied among these countries and their trading partners. We use intra-trade convergence and the difference-in-differences approach for the estimations. The results demonstrate that an increase in trade between the groups decreases the per capita income differential. Our results suggest that trade liberalization policies could be effective in achieving convergence. More importantly, we find that the per capita income of our source countries converged more rapidly under post-liberalization regimes than preliberalization regimes.
\end{abstract}

Keywords: Intra-trade, income convergence, per capita income, South Asia.

JEL Classification: C21.

\section{Introduction and Literature Review}

An extensive body of literature recognizes the link between trade and income convergence and divergence among countries (see studies based on cross-country growth regressions such as Baumol (1986), Dowrick and Nguyen (1989), Barro (1991), and Levine and Renelt (1992); studies that are based on beta convergence [regression toward the mean] such as Barro (1984), Barro and Sala-i-Martin (1992), Baumol (1986), and De Long (1988); and other sets of studies based on sigma convergence [concerning cross sectional dispersion] including Barro (1984), Dowrick and Nguyen (1989) among others). The theoretical relationship between trade and convergence is examined by incorporating the role of international trade and

\footnotetext{
* Faculty, College of Economics, Management and Information Systems, University of Nizwa, Oman.

${ }^{* *} \mathrm{PhD}$ candidate, School of Finance, Shanghai University of Finance and Economics, Shanghai.
} 
liberalization. The argument here is that trade liberalization causes a convergence in per capita income-since trade liberalization increases competition and domestic firms' absorption capacity for knowledge and ideas, knowledge levels among countries converge to a common level, leading to per capita income convergence (see Sachs and Warner (1995), Ben-David (1993, 1994a, 1994b, 1996, 2000) and Ben-David and Kimhi (2004) among others). Ben-David and Loewy (1998) posit a model that demonstrates how moving toward free trade increases trade volumes and reduces income differentials among liberalizing countries.

The evidence indicates a higher incidence of income convergence in some subsets of countries but no convergence tendencies among other subsets of wealthier countries (see Baumol, (1986), Baumol, et al (1989), Baldwin (2003), and Ben-David (1993, 1994b) among others). The literature based on endogenous growth demonstrates a lack of income convergence, ${ }^{1}$ [Romer (1986) and Lucas (1988)], but strong evidence of conditional convergence in studies such as Barro (1991), Mankiw, et al (1992), and Levine and Renelt (1992). ${ }^{2}$ These studies point toward a number of factors such as human capital and government policies that help account for convergence. Other studies such as Grossman and Helpman (1991) suggest that trade can contribute to the local knowledge stock and new ideas. Baldwin, et al (2001) argues that the exogenously falling cost of trade has resulted in technological externalities in the world's northern countries. However, studies based on endogenous models, such as Eicher (1999), result in income convergence. Young (1991) presents a static trade model based on five different equilibriums, most of which lead to convergence, and supports the idea that trade should generate convergence. Kravis (1970) argues that trade is only one of the various contributors to growth, and may not necessarily emerge as the dominant factor. In an earlier analysis, Corden (1971) combines the traditional theory of gains from trade with the growth models of Solow (1956) and Swan (1956), who argue that trade not only produces static gains but also increases capital accumulation and leads to higher growth of per capita output. Corden (1971) implies that a country

\footnotetext{
1 International trade can affect the economic growth rate but the effects may be considered 'level' or 'growth' effects or both. Pioneered by Romer (1986) and Lucas (1988), technology is assumed to be endogenously driven because investment in research and development advances technology that responds to market incentives. Romer and Batiz (1991) distinguish between level effects and growth effects. Roderick (1996) argues that "trade restrictions have level affects, but no growth effects. That is, a twenty percent tariff may reduce five percent of GDP, but it will not affect the long run growth rate of the economy."

${ }^{2}$ The greater the gap between initial per capita income level and long-run per capita income level, the faster the rate of convergence.
} 
that moves from autarky to free trade attains a higher steady-state income and as a result grows faster during the transition period. However, Johnson (1967), in the context of the Hickscher-Ohlin model, views the interplay of trade and growth from a different perspective.

These contributions hardly settle the debate on the level and growth effects of trade in the context of different countries. ${ }^{3}$ In addition to this, traditional growth literature, the neoclassical growth model [Solow 1956, and Koopman's (1965)] modifications imply that differences in initial capital and labor endowments, if eliminated over time, will cause convergence in per capita incomes. Barro and Martin (1991, 1992) and Mankiw, et al (1992) test this hypothesis across regions in the context of Solow (1956), where every country reaches its steady-state growth level independently of each other.

By integrating modern trade and neoclassical growth theories along with recent international data and evidence, one can trace the interplay of trade, growth, and income disparities. From aspects of traditional trade theory, the factor price equalization (FPE) theorem provides a base for equalizing factor prices when certain conditions are fulfilled [see Slaughter (1997)]. ${ }^{4}$ Slaughter (1997) also argues that per capita income might still diverge when factor quantities across the selected countries are dissimilar, even if the FPE theorem holds. Parikh and Shibata (2004) use panel data and the beta-sigma, single difference, and difference-in-differences approaches to convergence for pre-post liberalized eras, concluding that there is no evidence of acceleration or deceleration after liberalization for some Asian economies. The sigma-convergence approach shows significant convergence of per capita income, while the difference-in-differences approach also indicates a significant convergence. This study also uses dynamic models by using panel fixed effects; Generalized Method of Moments (GMM) estimations demonstrate no evidence of acceleration or deceleration in convergence.

The link between convergence and openness across history is noted by Williamson (1991) who argues that convergence and global economic

\footnotetext{
${ }^{3}$ Economists doubt whether trade has a growth effect [Dollar and Kraay (2001, 2003) and Srinivasan, (1999)]. In the context of the Cass-Koopmans model, Srinivasan holds "that one can obtain a positive long run growth effect of trade liberalization" conditioned on "a production function in which the marginal product of capital is bounded below by a sufficiently high positive value as capital labour- ratio goes to infinity."

${ }^{4}$ Samuelson (1971) shows that, in the standard specific-factors framework, free trade can generate convergence. Mokhtari and Rassekh (1989) find that the FPE theorem holds for 16 OECD countries for the period 1961-1984.
} 
integration is linked to the Industrial Revolution of 1850; there is evidence of convergence in two subperiods during which the movement of goods and factors occurred relatively freely, 1870-1913 and post-1950. According to this study, income gaps appear to grow over time; countries that trade extensively with one another tend to exhibit a higher incidence of income convergence. By testing for a negative relationship between average annual rates of growth and initial levels of income, Baumol (1986) concludes that industrial countries appear to belong to one convergence strand and middleincome countries to another, while low-income countries diverge over time. In a critical review of Sachs and Warner (1995), Rodriguez and Rodrik (2001) argue that the Sachs and Warner openness index is driven largely by black market premiums and the state monopoly of exports rather than trade policy.

Some points need to be emphasized. First, the mixed empirical results are similar to theoretical models on trade and convergence, but both theory and empirical evidence are inconclusive as to whether or not trade leads to income convergence, especially for South Asian countries that have liberalized their trade, financial, and industrial policies. Second, there is scant evidence to determine the magnitude of trade and extent of income convergence or divergence within the trading group of countries. Whether or not the rate of convergence, assuming it existed, is accelerated or decelerated after liberalization is questionable. Third, no study appears to have determined the rate of convergence for South Asian countries that have liberalized trade, or increasing trends in trade, investment, and bilateral economic relations with their trading partners. ${ }^{5}$ Fourth, most other studies are based on growth rates regressed on the initial level of income to determine convergence, while no structural breaks or pre- or postliberalization period studies have been taken into account. Fifth, most of these studies suffer from endogeneity, i.e., the problem of co-linking the relationship between trade liberalization and income convergence [see BenDavid (1993, 1994a, 1996)]. ${ }^{6}$ These studies examine various trade reform

\footnotetext{
${ }^{5}$ Although not used, the bilateral/trading group convergence, the only study by Parikh and Shibata (2004) on different regions (not including Pakistan and Bangladesh) used the beta and sigma convergence and difference-in difference approaches for Africa, Asia, and Latin America, and found no beta convergence in Asian countries and convergence in sigma and difference-in-difference approach.

6 Frankel and Romer (1999) tackle the endogeneity problem by employing a gravity model and creating an instrument based on countries that share a common border and are landlocked. Frankel and Rose (2002) test the hypothesis that a currency union stimulates trade among its constituent units, and that trade in turn stimulates output. Rodriguez and Rodrik (2001) criticize Frankel and Romer on the grounds that the Frankel and Rose
} 
programs and find significant convergence with significant increases in the volume of trade. They also prove that no convergence occurred prior to the implementation of trade reforms. Finally, if trade liberalization produces convergence in theory, then it should be evident for countries that are major trading partners rather than randomly selected countries.

The objectives of this paper, in addition to the aspects mentioned above, are (i) to measure the impact of the magnitude of trade and the intra-trade relationship before and after liberalization on bilateral and intragroup per capita income differentials for individual countries in South Asia by focusing on their trading partners; (ii) to examine the nature and rate of convergence or divergence for the countries in question; (iii) to determine whether or not the increasing trend of bilateral foreign direct investment (FDI) flows or bilateral investments, or increasing bilateral trade or trade openness policies, have a positive correlation with economic growth, thus leading to a reduction in income differentials. The policy outcomes that are expected to emerge from this study will help understand the dynamics of regional and bilateral free trade (including such agreements as SAFTA), individual countries' bilateral and free trade agreements, and the formulation of long-term development and economic objectives.

The remaining paper is organized as follows: Section II discusses the methodology and framework for analysis; Section III presents our empirical results and discussions; and Section IV provides concluding remarks and policy implications.

\section{Methodology}

A number of different approaches to convergence can be used to examine the magnitude of trade and extent of income convergence for the South Asian countries under study (Pakistan, India, Bangladesh, and Sri Lanka) by focusing on their trading partner countries before and after trade liberalization. Trade indicators such as the Sachs-Warner Index, Lerner Openness Index, growth rate of exports, tariff averages, collected tariff ratios, and black market premiums are used in different studies. However, the most common indicators are the openness index and trade dependency ratio (i.e., the ratio of exports and imports to gross domestic product [GDP]). ${ }^{7}$ Pre-liberalization and post-liberalization are defined as the periods 1972-1988 and 1989-2005, respectively. Although the selected

constructed trade share is not a valid instrument. For the debate on endogeneity, see Sachs (2003), Irwin and Tervio (2002), Cyrus (2004), and Ben-David (1996).

${ }^{7}$ See McCulloch and Cierea (2001). 
South Asian countries initiated trade liberalization differently and in different periods, these countries had already started to liberalize their trade policies in the period considered pre-liberalization. According to the World Bank, Sri Lanka initiated its trade liberalization policies in the mid1970s, while Pakistan and Bangladesh adopted trade liberalization policies after the mid 1980s. India initiated trade liberalization policies in 1990/91 [see Kumar (2005)]. These source countries adopted a number of policy steps such as tariff cuts and export-oriented measures along with financial liberalization. The main purpose of this study is to examine whether or not trade liberalization caused the per capita income of these countries to converge toward their trading partners over the sample period. Data on per capita income (in US\$ constant at 2000) and GDP data was taken from World Development Indicators (2006). Bilateral trade data was collected from various volumes of the Direction of Trade Statistics (an IMF publication).

\section{Trade and Income Convergence Approaches}

\section{(a) Intra-Group Convergence Approach}

\section{Construction of Trade Groups ${ }^{8}$}

The study focuses on four source countries: India, Pakistan, Sri Lanka, and Bangladesh. Each source country has 29 trading partners. The first five years are considered the initial period. Trading groups were formulated on the basis of exports and imports, and the magnitude of trade. Thus, each source country has four trading groups, giving us a total of sixteen trading groups. Group I includes all those trading partners that imported more than 4 percent of the exports of the source country during the initial period. The 4 percent is assumed to be a significant number that is incorporated for analysis based on their trade patterns. Group II consists of trading partners who imported less than 4 percent of the source country's exports during the first 5 years.

Two trading groups were created for each source country on the basis of imports. Group I includes all those trading partners from which the source country imported more than 4 percent of its imports during the first

${ }^{8}$ For intra-group convergence, we have followed the approach used by Ben-David (2004). 
5 years. Group II comprises trading partners from which the source country imported less than 4 percent of its imports during the first 5 years.

The total volume of trade for each intra-trade group is calculated for each export-based and import-based group for each year from 1972 to 2005 . To obtain a measure of how the source country's trade with its trading partners grew relative to its GDP, we divide the total volume of intra-trade by the GDP of the source country. ${ }^{10}$ This ratio is represented by the variables $\mathrm{R}_{\mathrm{i}, \mathrm{t}}^{x}$ and $\mathrm{R}^{m}{ }_{\mathrm{it}}$ (where $\mathrm{i}$ stands for source country and the superscripts $\mathbf{x}$ and $\mathrm{m}$ denote the group as being export-based or import-based, respectively), which are calculated for each trading group over the sample period. When regressed on trend $\left(T_{t}\right)$, these trade ratios give us

$$
\begin{aligned}
& \mathrm{R}_{\mathrm{it}}^{x}=\alpha_{1, \mathrm{i}}^{x}+\alpha_{2, \mathrm{i}}^{x} \mathrm{~T}_{\mathrm{t}}+\varepsilon^{x}{ }_{\mathrm{it}} \\
& \mathrm{R}^{\mathrm{m}}{ }_{\mathrm{it}}=\alpha^{\mathrm{m}}{ }_{1, \mathrm{I}}+\alpha^{\mathrm{m}}{ }_{2, \mathrm{i}} \mathrm{T}_{\mathrm{t}}+\varepsilon^{\mathrm{m}}{ }_{\mathrm{it}}
\end{aligned}
$$

The results of the above equations are reported in Table- 1 . The overall trade ratio behavior depicts an increasing trend over the sample period. Does an increasing trend cause per capita income to converge across the trading groups? Our main assumption is that trade, along with other factors, causes per capita income to converge within the intra-trade groups. The study uses a number of control variables as other factors. These include size, population, output, distance, political stability, and special attributes of trading partners. However it is neither feasible nor convenient to incorporate all the control variables in estimating the intra-trade group equation. ${ }^{11}$

\section{Convergence Model for Intra-Trade Group}

Our intra-trade estimation results show an increasing trend over the sample period, making it possible to examine the behavior of each group's

\footnotetext{
${ }^{9}$ We include these trading partners in our analysis for a broader picture. Were only major trading partners taken into account, we might lose out on group size. Although some countries traded less in the initial period, their trade share increased over time.

${ }^{10}$ Our methodology for constructing the trade ratio differs somewhat from Ben-David and Kimhi (2000), where the trade ratio is the ratio of total intra-group trade to the group's aggregate GDP. Our main interest is to determine whether income convergence results from an increase in source countries' volume of trade.

${ }^{11}$ The estimation process for control variables is tricky in the case of the intra-trade group. We have thus excluded this option and used Ben-David's (1996) method of convergence.
} 
income differential over the sample period and any evidence of income convergence within the groups.

The convergence measure adopted here is the same used by BenDavid (1996):

$$
\left(y_{i, t}-\bar{y}_{t}\right)=\phi\left(y_{i, t-1}-\bar{y}_{t-1}\right)+\varepsilon_{i, t}
$$

where $y_{i, t}$ denotes the $\log$ of source country's per capita income at time $\mathrm{t}$ and $\bar{y} t$ gives the average of the concerned group's log of per capita incomes at time $\mathrm{t}, \varepsilon_{i, t}$ is an error term, and $\varphi$ is a convergence (divergence) parameter. A positive (negative) $\varphi$ demonstrates the convergence (divergence) of per capita income in the group. It also indicates the rate of convergence within a given trading group. The data for countries within each group are pooled together to estimate equation (3) and $\varphi$ is calculated to examine the income convergence rate for each group.

The Augmented-Dickey-Fuller (ADF) form of equation (3) can be written as follows:

$$
z i, t=\phi z i, t-1+\sum_{j=1}^{k} c_{j} \Delta z i, t-j+\varepsilon i, t
$$

where $z i, t=\left(y_{i, t}-\bar{y}_{t}\right)$ and $\Delta z_{i, t}=z_{i, t} z_{i, t-1}$. In corroboration with Ben-David (1996), the number of lags, $\mathrm{k}$, is determined by setting an upper bound of $k$ $\max =4$ and thereafter estimating the equation. If the coefficient is not significant at the last lag, then $\mathrm{k}$ is reduced by one lag and thereafter to repeat the estimation procedure. ${ }^{12}$ The results are reported in Table- 2.

\section{(b) Difference-in-Differences Approach}

A typical difference-in-differences approach can be used by following Meyer (2004) and Slaughter (2001). This is used to determine when some economic agents apply some policy "treatment" at a single point in time; outcome can then be observed both for before and after the application of the treatment.

This approach is used to capture the trade liberalization effect on per capita income convergence among the liberalizing countries and their

\footnotetext{
12 Although other approaches have been used to measure convergence, this measure is more appropriate in terms of usage, simplicity, and applicability to small samples.
} 
trade partners for both pre- and post-liberalization periods. To examine this proposition, the difference-in-differences approach gauges convergence patterns among liberalized countries pre- and post-liberalization with the convergence behavior of control countries in both periods.

The difference-in-differences equation to be estimated can be written as follows:

$\sigma(y)_{j r t}=\alpha_{1}+\alpha_{2}\left(d_{r}\right)+\alpha_{3}\left(d_{j}\right)+\alpha_{4}\left(d_{j r}\right)+\beta_{1}(t)+\beta_{2}(t)\left(d_{r}\right)+\beta_{3}(t)\left(d_{j}\right)+\beta_{4}(t)\left(d_{j r}\right)+\varepsilon_{j r t}$

Per capita income dispersion within each group at each point in time is measured and denoted by $\sigma(y)_{j r}$. The subscript $j$ shows two groups of countries: $j=0$ and $j=1$ for the pre-liberalizing group and control group, respectively. The subscript $r$ index indicates pre- and post-liberalization periods with $r=0$ and $r=1$ for the former and latter, respectively. Similarly, $t$ stands for time periods, $\mathrm{d}$ is a set of dummy variables, and $\varepsilon_{j r t}$ is a white noise error term.

As given earlier, the trade liberalized group comprises Pakistan, India, Sri Lanka, and Bangladesh. Each has one trade liberalized group along with three control groups of their trading partners. The control groups were constructed based on the "similarity criteria" given in Slaughter (1998).

The first control group consisted of all trading partners in the trade liberalized group, the second group consisted of all Asian countries, and the third group comprised all non-Asian trading partners.

Equation (5) estimates an individual intercept term and per capita income convergence rate for each liberalizing and control group for both pre- and post-liberalization periods. These are given below:

\begin{tabular}{lll}
\hline Country Group/Regime & Intercept & Convergence Rate \\
\hline Liberalizing group pre-liberalization & $\alpha 1$ & $\beta 1$ \\
Liberalizing group post-liberalization & $\alpha 1+\alpha 2$ & $\beta 1+\beta 2$ \\
Control group pre-liberalization & $\alpha 1+\alpha 3$ & $\beta 1+\beta 3$ \\
Control group post-liberalization & $\alpha 1+\alpha 2+\alpha 3+\alpha 4$ & $\beta 1+\beta 2+\beta 3+\beta 4$ \\
\hline
\end{tabular}


A positive (negative) rate reveals convergence (divergence) in the above notation. The calculation of difference-in-differences of estimated rates demonstrates the impact of trade liberalization on per capita income convergence. For instance, the difference in convergence rates within the liberalizing group for pre- and post-liberalization period is $\left(\beta_{1}+\beta_{2}\right)-\beta_{1}=\beta_{2}$. Similarly, the difference in convergence rates within the control group is given by $\left(\beta_{1}+\beta_{2}+\beta_{3}+\beta_{4}\right)-\left(\beta_{1}+\beta_{3}\right)=\beta_{2}+\beta_{4}$. Thus, the difference in differences (between the liberalizing and control groups) is $\left(\beta_{2}+\beta_{4}\right)-\beta_{2}=\beta_{4}$. The parameter $\beta_{4}$ quantifies the change in pre- and post-liberalization convergence rates within the liberalizing group relative to the control group.

The main assumption in equation (5) is that the only difference between the two groups is the trade-policy change. Thus, $\beta_{4}$ will be positive (negative) if trade leads to the convergence (divergence) of per capita income.

\section{Results and Discussion}

\section{A. Intra-Group Convergence Approach}

Table-1 reports the trend behavior of the intra-trade ratio of exportbased groups and import-based groups [equations (1) and (2)] over time. The coefficients of the trade ratio have positive signs for all groups, which indicates an increase in the trade ratio over time. Eight export-based groups (except Group I for Pakistan) show positive significant trade ratio coefficients. The import-based groups also show an increasing trend in the trade ratio over the sample period.

The results of equation (4) are reported in Table-2. Table-2a consists of export-based groups and Table-2b presents the results for import-based groups. The trade groups are listed according to source country. The coefficient of income convergence, $\varphi$, for most of the trade groups is positive and lies within the unit number. These findings imply that trade leads to the convergence of per capita income among the groups. A few groups demonstrate income divergence, but the overall results support the idea that trade is one of several significant determinants that influences per capita income and leads it to converge.

We have focused on selected South Asian countries and their trading partners, although there are other ways of comparing trade groups with 
countries other than trading partners by considering geographic characteristics, etc.

\section{B. Difference-in-Differences Approach}

Prior to estimating the difference-in-difference regressions, the rates of per capita income convergence within the liberalizing group for pre- and post-liberalization periods are examined by employing the following singledifference regression.

$$
\sigma(y)_{j r t}=\alpha_{1}+\alpha_{2}\left(d_{r}\right)+\beta_{1}(t)+\beta_{2}(t)\left(d_{r}\right)+u_{j r t}
$$

where all variables have been defined earlier, $\boldsymbol{u}_{j r t}$ is a white-noise additive error term, and $\beta_{2}$ captures the effect of trade liberalization within the liberalizing group in absolute terms. However, it does not indicate any relative comparison across the liberalizing and control groups.

The result of equation (6) is reported in Table-3. The estimated results indicate a divergence in income in the pre-liberalization period for the liberalizing group, and convergence in the post-liberalization period.

The estimated results of main equation (5) are reported in Tables-4 and 5. Table-4 displays the convergence rates for the control groups in both pre-and post-liberalization periods. According to these results, three control groups produce a mixed outcome. For instance, in the case of all trading partner countries, there is income convergence in the pre-liberalization period and income divergence in the post-liberalization period. In the case of non-Asian trade partner countries, there is divergence in the preliberalization period and again in the post-liberalization period. Asian trading partner countries demonstrate income convergence in both periods.

Table-5 represents the difference-in-differences between the liberalizing and control groups. The calculated difference positive coefficient $\beta_{4}$ demonstrates income convergence among liberalizing countries and control group countries during the post-liberalizing period. As explained above, the positive (negative) value of $\beta_{4}$ indicates that trade liberalization in the liberalizing group tends to cause income convergence (divergence) over the post-liberalization period. Overall, our results favor the proposition that income converges.

Although there are arguments against the use of the difference-indifferences approach in that it does not provide clear-cut consequences of trade policies, it remains promising for trade liberalization advocates. 


\section{Conclusion and Policy Implications}

This study was an attempt to examine the impact of trade liberalization on the per capita income convergence of selected South Asian countries and their trade partners for the sample period 1972-2005. Two types of approaches, the intra-trade approach and difference-in-differences approach, were employed.

Our results demonstrate that the intra-trade ratio increases over time. We adopted the convergence methodology of Ben-David (1996) to examine whether or not increasing trade among groups of countries causes their per capita income to converge over the sample period. The results show that the most trade groups exhibited income convergence.

The outcomes of pre-and post-trade liberalization were examined using the difference-in-differences approach. The liberalizing group of countries consisted of selected South Asian countries, while three control groups were constructed to examine the impact of trade liberalization, especially in terms of pre- and post-liberalization. Overall, the results of both approaches indicate that trade, along with other factors, tends to cause per capita income convergence across trading partners.

This implies that liberalization policies have helped trading countries grow more rapidly in terms of per capita income, thus increasing their convergence rate. The convergence in per capita income can also be explained by other factors, but the effects of liberalization cannot be ignored. The study considers testing the period of liberalization using different approaches but does not look at the impact of tariff cuts and other economic or social variables. Nor does it take into account the impact of different economic policies during different periods by the countries in question. 


\section{References}

Baldwin, R.E. (2003). Openness and Growth: What's the Empirical Relationship? National Bureau of Economic Research, Working Paper No. 9578.

Baldwin, R.E., Martin, P., and Ottaviano, G. (2001). Global Income Divergence, Trade, and Industrialization: The Geography of Growth Take-Offs. Journal of Economic Growth, 6, 5-37.

Barro, R. J., and Sala-i-Martin, X. (1991). Convergence across States and Regions. Brookings Papers on Economic Activity, 107-82.

Barro, R.J. (1984). Macroeconomics. (1st ed.). Wiley: New York.

Barro, R.J. (1991). Economic Growth in a Cross-Section of Countries. Quarterly Journal of Economics, 106, 407-443.

Barro, R.J., and Sala-I-Martin, X. (1992). Convergence. Journal of Political Economy, 100, 223-51.

Baumol, W.J. (1986). Productivity Growth, Convergence, and Welfare: What the Long-Run Data Show. American Economic Review, 76, 1072-85.

Baumol, W.J., Blackman, S.B., and Wolff, E.N. (1989). Productivity and American Leadership: The Long View, Cambridge, MA: MIT Press.

Ben-David B., and Loewy, M.B. (1998). Free Trade, Growth, and Convergence. Journal of Economic Growth, 3(2).

Ben-David, D. (1993). Equalizing Exchange: Trade Liberalization and Income Convergence. Quarterly Journal of Economics, 108, 653-79.

Ben-David, D. (1994a). Income Disparity among Countries and the Effects of Freer Trade. Economic Growth and the Structure of Long Run Development, in Luigi L. Pasinetti and Robert M. Solow (eds), London: Macmillan, 45-64.

Ben-David, D. (1994b). Convergence Clubs and Diverging Economies. CEPR Working Paper No. 922.

Ben-David, D. (1996). Trade and Convergence among Countries. Journal of International Economics, 40, 279-98. 
Ben-David, D. (2000). Trade Growth and Disparity among Nations. From Income Disparity and Poverty, World Trade Organization Special Study 5, Geneva: WTO publications, 11-42.

Ben-David, D., and Kimhi, A. (2004). Trade and the Rate of Income Convergence. Journal of International Trade \& Economic Development, 13(4), 419-41.

Ben-David, D., and Loewy, M.B. (1998). Free Trade, Growth, and Convergence. Journal of Economic Growth, 3, 143-70.

Corden, W.M. (1971). The Effects of Trade on the Rate of Growth. In Bhagwati, J.N. et a1. (eds) Trade, Balance of payment And Growth. Amsterdam: North Holland, 117-43.

Cyrus, T. (2004). Does Convergence cause Trade, or Does Trade cause Convergence? The Journal of International Trade and Economic Development, 13(4), 397-418.

Delong, B. (1988). Productivity Growth, Convergence and Welfare: Comment. American Economic Review, 78, 1138-54.

Dollar, D., and Kraay, A. (2001). Trade, Growth and Poverty. Development Research Group, The World Bank, Washington.

Dollar, D., and Kraay, A. (2003). Institutions, Trade, and Growth. Journal of Monetary Economics, 50, 133-62.

Dowrick, S., and Nguyen, D. (1989). OECD Comparative Economic Growth 1950-85: Catch-Up and Convergence. American Economic Review, 79, 1010-30.

Eicher T., and Turnovsky, S. (1999). A Generalized Model of Economic Growth. Economic Journal, 109, 394-415.

Franke1, J., and Romer, D. (1999). Does Trade cause Growth? The American Economic Review, 89, 379-99.

Franke1, J., and Rose, A. (2002). An Estimate of the Effect of Common Currencies on Trade and Income. The Quarterly Journal of Economics, 117, 437-65.

Grossman, G., and Helpman, E. (1991). Innovation and Growth in the Global Economy. Cambridge: The MIT Press. 
Grossman, G., and Helpman, E. (1991). Trade, Knowledge Spillovers, and Growth. European Economic Review, 35, 517-26.

IMF. Direction of Trade Statistics, Various Volumes, IMF publications.

Irwin, D., and Tervio, M. (2002). Does Trade raise Income? Evidence from the Twentieth Century. Journal of International Economics, 58, 1-18.

Johnson, H.G. (1967). International Trade and Economic Growth, Cambridge, MA: Harvard University Press.

Koopmans, T.C. (1965). On the Concept of Optimal Economic Growth. In The Econometric Approach to Development Planning, Amsterdam, North-Holland for Pontificia Acad.

Kravis B. (1970). Trade as a Handmaiden of Growth: Similarities between the Nineteenth and Twentieth Centuries. The Economic Journal, $80(3), 850-72$.

Levine, R., and Renelt, D. (1992). A Sensitivity Analysis of Cross-Country Growth Regressions. American Economic Review, 82, 942-63.

Lucas, R.E. Jr. (1988). On the Mechanics of Development Planning. Journal of Monetary Economics, 22(1), 1-42.

Mankiw, N.G., Romer, D., and Weil, D. (1992). A Contribution to the Empirics of Economic Growth. Quarterly Journal of Economics, 107(2), 407-37.

Mc Culloch, N.L., and Cierea, X. (2001). Trade Liberalization and Poverty: A Hand Book. Centre for Economic Policy Research, London.

Meyer, B. (2004). Natural and Quasi-Experiments in Economics. National Bureau of Economic Research, Technical Paper No.170.

Mokhtari, M. and Rassekh, F. (1989). The Tendency Towards Factor Price Equalization Theorem among OECD Countries. The Review of Economics and Statistics, 71(4), 636-42.

Parikh, A., and Shibata, M. (2004). Does Trade Liberalization Accelerate Convergence in Per Capita Incomes in Developing Countries? Journal of Asian Economics, 15(1), 33-48.

Rodrik, D. (1996). Understanding Economic Reform Policy. Journal of Economic Literature, 34(1), 9-41. 
Rodriguez, F., and Rodrik, D. (2001). Trade Policy and Economic Growth: A Sceptic's Guide to the Cross-National Evidence. In Bernanke, B.S. and Rogoff, K. (eds) NBER Macroeconomics Annual 2000, Cambridge: MIT Press, 261-325.

Romer P., and Rivera-Batiz, L. (1991). International Trade with Endogenous Technical Change. European Economic Review, 35, 971-1001.

Romer, P.M. (1986). Increasing Returns and Long-Run Growth. Journal of Political Economy, 94(5), 1002-37.

Sachs, J.D. (2003). Institutions Don't Rule: Direct Effects of Geography on Per Capita Income. National Bureau of Economic Research, Working Paper, 94-90.

Sachs, J.D., and Warner, A. (1995). Economic Reform and the Process of Global Integration. Brookings Papers on Economics Activity 1, 1-118.

Samuelson, P. (1971). Ohlin Was Right. Swedish Journal of Economics, 73, 365-384.

Slaughter, M.J. (1997). Per Capita Income Convergence and the Role of International Trade. The American Economic Review, 87(2), 473-85.

Slaughter, M.J. (2001). Trade Liberalization and Per Capita Income Convergence: A Difference-in-Difference Analysis. Journal of International Economics, 55(1), 203-28.

Solow, R.M. (1956). A Contribution to the Theory of Economic Growth. Quarterly Journal of Economics, 70(1), 65-94.

Srinivasan, T.N. (1999). Trade Orientation, Trade Liberalization, and Economic Growth. The University of Michigan Press, 155-96.

Swan, T.W. (1956). Economic Growth and Capital Accumulation. Economic Record, 32(2), 334-61.

Williamson, J.G. (1991). Economic Convergence: Placing Post-Famine Ireland in Comparative Perspective. Harvard Institute of Economic Research Working Papers with number 1654.

Young A. (1991). Learning by Doing and the Dynamic Effects of International Trade. Quarterly Journal of Economics, 106, 369-405. 
Table-1: Regression of Groups Trade Ratio on Trend

\begin{tabular}{|c|c|c|c|c|c|c|}
\hline \multicolumn{4}{|c|}{$\begin{array}{c}\text { Export-based groups } \\
\mathrm{R}_{\mathrm{it}}^{x}=\alpha_{1, \mathrm{i}}^{x}+\alpha_{2, \mathrm{i}}^{x} \mathrm{~T}_{\mathrm{t}}+\varepsilon_{\mathrm{it}}^{x}\end{array}$} & \multicolumn{3}{|c|}{$\begin{array}{l}\text { Import-based groups } \\
\mathrm{R}^{\mathrm{m}}{ }_{\mathrm{it}}=\alpha^{\mathrm{m}}{ }_{1, \mathrm{i}}+\alpha^{\mathrm{m}}{ }_{2, \mathrm{i}} \mathrm{T}_{\mathrm{t}}+\varepsilon^{\mathrm{m}}{ }_{\mathrm{it}}\end{array}$} \\
\hline Source Country & $\left\langle 1, \mathbf{i}^{\mathbf{X}}\right.$ & $\mathfrak{I}_{2, \mathbf{i}^{\mathrm{x}}}$ & $\mathrm{R}$ & $\left\langle 1, \mathrm{i}^{\mathrm{m}}\right.$ & $\left\langle 2, \mathrm{i}^{\mathrm{m}}\right.$ & $\overline{\mathrm{R}}$ \\
\hline Pakistan G01 & $\begin{array}{l}12.091 \\
(19.34)^{*}\end{array}$ & $\begin{array}{l}0.0163 \\
(0.50)\end{array}$ & 0.007 & $\begin{array}{l}9.945 \\
(19.83)^{*}\end{array}$ & $\begin{array}{l}0.0145 \\
(0.54)\end{array}$ & 0.009 \\
\hline India GO1 & $\begin{array}{l}3.50 \\
(12.38)^{*}\end{array}$ & $\begin{array}{l}0.098 \\
(6.49)^{*}\end{array}$ & 0.57 & $\begin{array}{l}3.36 \\
(13.45)^{*}\end{array}$ & $\begin{array}{l}0.080 \\
(5.97)^{*}\end{array}$ & 0.53 \\
\hline Sri Lanka G01 & $\begin{array}{l}13.7 \\
(10.31)^{*}\end{array}$ & $\begin{array}{l}0.488 \\
(7.12)^{*}\end{array}$ & 0.62 & $\begin{array}{l}13.68 \\
(10.54)^{*}\end{array}$ & $\begin{array}{l}0.587 \\
(8.41)^{*}\end{array}$ & 0.69 \\
\hline Bangladesh G01 & $\begin{array}{l}2.81 \\
(7.63)^{*}\end{array}$ & $\begin{array}{l}0.196 \\
(9.97)^{*}\end{array}$ & 0.76 & $\begin{array}{l}3.41 \\
(13.51)^{*}\end{array}$ & $\begin{array}{l}0.163 \\
(12.06)^{*}\end{array}$ & 0.82 \\
\hline Pakistan G02 & $\begin{array}{l}4.30 \\
(11.5)^{*}\end{array}$ & $\begin{array}{l}0.123 \\
(6.15)^{*}\end{array}$ & 0.54 & $\begin{array}{l}6.44 \\
(12.68)^{*}\end{array}$ & $\begin{array}{l}0.125 \\
(4.600) *\end{array}$ & 0.41 \\
\hline India G02 & $\begin{array}{l}0.55 \\
(2.58)^{*}\end{array}$ & $\begin{array}{l}0.16 \\
(14.58)^{*}\end{array}$ & 0.87 & $\begin{array}{l}0.68 \\
(12.68)^{*}\end{array}$ & $\begin{array}{l}0.186 \\
(4.59) *\end{array}$ & 0.87 \\
\hline Sri Lanka G02 & $\begin{array}{l}5.05 \\
(5.88)^{*}\end{array}$ & $\begin{array}{l}0.53 \\
(11.64)^{*}\end{array}$ & 0.81 & $\begin{array}{l}3.26 \\
(4.33)^{*}\end{array}$ & $\begin{array}{l}0.44 \\
(10.99) *\end{array}$ & 0.80 \\
\hline Bangladesh G02 & $\begin{array}{l}2.74 \\
(12.99) *\end{array}$ & $\begin{array}{l}0.20 \\
(17.85)^{*}\end{array}$ & 0.91 & $\begin{array}{l}2.13 \\
(8.20)^{*}\end{array}$ & $\begin{array}{l}0.23 \\
(16.8)^{*}\end{array}$ & 0.90 \\
\hline
\end{tabular}

$\mathrm{t}$-statistics are in parenthesis. The number of observations is 33 in each of the estimations.

* $x$ and $m$ denote trade groups based on exports and imports respectively.

Table-2(a): Trade Group's Convergence Coefficients Export-based Groups

\begin{tabular}{lcccc}
\hline Source country/Group & No. of countries & $\phi$ & t-statistics & $\mathbf{k}$ \\
\hline Pakistan G01 & 9 & -0.668 & $-4.69^{*}$ & 1 \\
Pakistan G02 & 20 & 0.475 & $2.63^{*}$ & 4 \\
India G01 & 11 & 0.607 & $3.25^{*}$ & 4 \\
India G02 & 19 & 0.377 & $2.90^{*}$ & 3 \\
Sri Lanka G01 & 7 & 0.642 & $3.82^{*}$ & 4 \\
Sri Lanka G02 & 22 & -0.396 & $-2.43^{*}$ & 3 \\
Bangladesh G01 & 8 & 0.175 & $4.77^{*}$ & 4 \\
Bangladesh G02 & 21 & 0.385 & $7.44^{*}$ & 4 \\
\hline
\end{tabular}

The number of observations is 29 in each of the estimations. The list of countries in each group is in the appendix. ${ }^{*}$ denotes the significance level at $5 \%$. 
Table-2(b): Import-based Groups

\begin{tabular}{lcccc}
\hline Source country/Group & No. of countries & $\varphi$ & t-statistics & $\mathbf{k}$ \\
\hline Pakistan G01 & 7 & 0.649 & $4.76^{*}$ & 3 \\
Pakistan G02 & 22 & 0.594 & $3.39^{*}$ & 3 \\
India G01 & 9 & 0.639 & $3.62^{*}$ & 4 \\
India G02 & 19 & -0.802 & $-4.59^{*}$ & 4 \\
Sri Lanka G01 & 10 & 0.753 & $4.85^{*}$ & 3 \\
Sri Lanka G02 & 19 & -0.554 & $-4.11^{*}$ & 3 \\
Bangladesh G01 & 14 & 0.403 & $3.61^{*}$ & 4 \\
Bangladesh G02 & 15 & -0.524 & $-4.41^{*}$ & 3 \\
\hline
\end{tabular}

The number of observations is 29 in each of the estimations. The list of countries in each group is in the appendix. * denotes the significance level at $5 \%$.

Table-3: Difference in Differences in Rates of Per Capita Income Convergence Pre and Post-Liberalization for Liberalizing Group

\begin{tabular}{|c|c|c|c|c|}
\hline $\begin{array}{l}\text { Case } \\
\text { Name }\end{array}$ & $\begin{array}{c}\text { Pre-liberalization } \\
\text { convergence rate, } \\
\beta 1\end{array}$ & $\begin{array}{c}\text { Post-liberalization } \\
\text { Convergence rate, } \\
\beta 1+\beta 2\end{array}$ & $\begin{array}{c}\text { Difference in } \\
\text { convergence } \\
\text { Rate } \beta 2\end{array}$ & $\begin{array}{l}\text { Number of } \\
\text { Observations }\end{array}$ \\
\hline $\begin{array}{l}\text { Selected } \\
\text { South } \\
\text { Asian } \\
\text { Countries }\end{array}$ & $\begin{array}{c}0.0126 \\
(6.664)^{*}\end{array}$ & $\begin{array}{l}-0.0027 \\
(-2.76)^{*}\end{array}$ & -0.0153 & 16 \\
\hline
\end{tabular}

As explained in the text, the liberalizing group consists on four South Asian countries; Pakistan, India, Sri Lanka and Bangladesh. T-statistics are reported in parenthesis.* denotes significance at the 5\% level. 
Table-4: Control Groups

\begin{tabular}{|c|c|c|c|c|}
\hline $\begin{array}{c}\text { Case } \\
\text { Name }\end{array}$ & $\begin{array}{c}\text { Pre- } \\
\text { liberalization } \\
\text { convergence } \\
\text { rate }\end{array}$ & $\begin{array}{c}\text { Post- } \\
\text { liberalization } \\
\text { Convergence } \\
\text { rate, }\end{array}$ & $\begin{array}{c}\text { Difference in } \\
\text { convergence } \\
\text { Rate }\end{array}$ & $\begin{array}{c}\text { Number of } \\
\text { Control } \\
\text { Countries }\end{array}$ \\
\hline $\begin{array}{l}\text { All Trade } \\
\text { partner } \\
\text { countries }\end{array}$ & $\begin{array}{l}-0.00526 \\
(-3.104)^{*}\end{array}$ & $\begin{array}{c}0.006 \\
(3.67)^{*}\end{array}$ & 0.011 & 26 \\
\hline $\begin{array}{l}\text { Asian trade } \\
\text { partner } \\
\text { Countries }\end{array}$ & $\begin{array}{c}-0.00105 \\
(-2.56)^{*}\end{array}$ & $\begin{array}{l}-0.0025 \\
(-2.81)^{*}\end{array}$ & -0.0014 & 6 \\
\hline $\begin{array}{l}\text { Non-Asian } \\
\text { trade } \\
\text { partner } \\
\text { Countries } \\
\end{array}$ & $\begin{array}{c}0.001204 \\
(1.42)\end{array}$ & $\begin{array}{l}-0.0013 \\
(-7.21)^{*}\end{array}$ & -0.0025 & 20 \\
\hline
\end{tabular}

Reading across the columns, reports the following parameters $(\beta 1+\beta 3) ;(\beta 1+\beta 2+\beta 3+\beta 4)$ and $\beta 2+\beta 4$.T-statistics are reported in the parenthesis. ${ }^{*}$ denotes the significance level at $5 \%$.

Table-5: Difference in Differences in Rates of Per Capita Income Convergence Pre vs. Post-Liberalization; Liberalizing vs. Control Countries

\begin{tabular}{|c|c|c|c|}
\hline $\begin{array}{c}\text { Case } \\
\text { Name }\end{array}$ & $\begin{array}{l}\text { Difference-in- } \\
\text { Differences Estimate } \\
\text { among all trade } \\
\text { partner countries } \beta 4\end{array}$ & $\begin{array}{c}\text { Difference -in- } \\
\text { Differences Estimate } \\
\text { among Asian trade } \\
\text { partner countries } \beta 4 \\
\end{array}$ & $\begin{array}{c}\text { Difference-in- } \\
\text { Differences Estimate } \\
\text { among Non-Asian trade } \\
\text { partner countries } \beta 4\end{array}$ \\
\hline $\begin{array}{l}\text { Selected } \\
\text { South } \\
\text { Asian } \\
\text { Countries }\end{array}$ & 0.0213 & 0.0139 & 0.0128 \\
\hline
\end{tabular}




\section{Appendix}

\section{List of Countries}

Table-A1: Trade Groups i) Export-Based trade groups

\begin{tabular}{ll}
\hline $\begin{array}{c}\text { Source country/ } \\
\text { group }\end{array}$ & \multicolumn{1}{c}{ Trade partner countries } \\
\hline Pakistan G01 & AUST, CAND, GER, HK, INDO, ITY, JAP, U.K, U.S.A \\
Pakistan G02 & AUT, BD, BELG, DEN, FIN, FRA, GRE, IND, IRE, \\
& $\begin{array}{l}\text { KOR, MAL, NETH, NEZ, NOR, POR, SING, SPA,SRI, } \\
\text { SWED, SWZ }\end{array}$ \\
India G01 & AUST, CAND, FRA, GER, HK, INDO, ITY, JAP, KOR, \\
India GO2 & U.K, U.S.A \\
Sri Lanka G01 & NOR, PAK, POR, SING, SPA, SRI, SWED, SWZ \\
Sri Lanka G02 & AUST, CAND, GER, IND, JAP, U.K, U.S.A \\
& ITY, KOR, MAL, NETH, NEZ, NOR, PAK, POR, \\
& SING, SPA, SWED, SWZ, \\
Bangladesh G01 & BELG, CAND, GER, IND, JAP, SING, U.K, U.S.A \\
Bangladesh G02 & AUST, AUT, DEN, FIN, FRA, IND, KOR, MAL, \\
& NETH, NEZ, NOR, PAK, POR, SPA,SRI, SWED, SWZ \\
\hline
\end{tabular}


Table-A2: Import-based Group

\begin{tabular}{ll}
\hline $\begin{array}{c}\text { Source country/ } \\
\text { group }\end{array}$ & \multicolumn{1}{c}{ Trade partner countries } \\
\hline Pakistan G01 & AUST,CAND,GER,HK,JAP, U.K,U.S.A \\
Pakistan G02 & AUT, BD, BELG, DEN, FIN, FRA, IND, IRE, KOR, \\
& MAL, NETH, NEZ, NOR, POR, SING, SPA,SRI, \\
& SWED, SWZ, INDO, HK, \\
India G01 & AUST, BELG, CAND, DEN, FIN, FRA, GER, HK, \\
& INDO, ITY, JAP, KOR, MAL, NETH, NEZ, SING, \\
& SRI, SWED, U.K, U.S.A \\
India GO2 & NOR, AUT, BD, GRE, IRE, PAK, SPA, SWZ \\
Sri Lanka G01 & AUST, CAND, FRA, GER, HK, IND, INDO, ITY, JAP, \\
Sri Lanka G02 & AUT, BD, BELG, DEN, FIN, GRE, IRE, NETH, NEZ, \\
& NOR, PAK, POR, SING, SPA, SWED \\
Bangladesh G01 & AUST, BELG, CAND, FRA, GER, HK, IND, INDO, \\
& ITY, JAP, KOR, U.K, U.S.A \\
Bangladesh G02 & AUT,DEN,FIN,GRE,IRE,MAL,NETH,NEZ,NOR, \\
& PAK,POR,SING,SPA,SRI, SWED,SWZ, \\
\hline
\end{tabular}

Table-A3: Liberalizing and Control Groups

\begin{tabular}{l}
\hline \multicolumn{1}{c}{ Liberalizing Group } \\
\hline PAK, INDIA, BANGLADESH, SRI LANKA \\
\hline \multicolumn{1}{c}{ Control Groups } \\
\hline ALL COUNTRIES \\
AUST, AUT,BELG,CAND,DEN,FIN,FRA,GER, GRE, HK, INDO, IRE, ITY, \\
JAP, KOR, MAL, NETH, NEZ, NOR, POR, SING, SPA, SWED, SWZ, \\
U.K, U.S.A \\
ASIAN GROUP \\
HK, INDO, JAP, KOR, MAL, SING, \\
NON-ASIAN GROUP \\
AUST, AUT, BELG, CAND, DEN, FIN, FRA, GER, GRE, IRE, ITY, \\
NETH, NEZ, NOR, POR, SPA, SWED, SWZ, U.K, U.S.A \\
\hline
\end{tabular}


Table-A4: Legend of Countries

\begin{tabular}{|c|c|c|}
\hline & Code & Country \\
\hline 1 & AUST & Austrailia \\
\hline 2 & AUT & Austria \\
\hline 3 & $\mathrm{BD}$ & Bangladesh \\
\hline 4 & BELG & Belgium \\
\hline 5 & CAND & Canada \\
\hline 6 & DEN & Denmark \\
\hline 7 & FIN & Finland \\
\hline 8 & FRA & France \\
\hline 9 & GER & Germany \\
\hline 10 & GRE & Greece \\
\hline 11 & HK & Hong Kong \\
\hline 12 & IND & India \\
\hline 13 & INDO & Indonesia \\
\hline 14 & IRE & Ireland \\
\hline 15 & ITY & Italy \\
\hline 16 & JAP & Japan \\
\hline 17 & KOR, & Korea \\
\hline 18 & MAL & Malaysia \\
\hline 19 & NETH & Nether Land \\
\hline 20 & NEZ & New Zealand \\
\hline 21 & NOR & Norway \\
\hline 22 & PAK & Pakistan \\
\hline 23 & POR & Portugal \\
\hline 24 & SING, & Singapore \\
\hline 25 & SPA & Spain \\
\hline 26 & SRI & Sri Lanka \\
\hline 27 & SWED & Sweden \\
\hline 28 & SWZ, & Switzerland \\
\hline 29 & U.K & United Kingdom \\
\hline 30 & U.S.A & United States \\
\hline
\end{tabular}

